\title{
Ammonia emissions from an anaerobic digestion plant estimated using atmospheric measurements and dispersion modelling
}

\author{
Michael W. Bell ${ }^{\mathrm{a}, \mathrm{b}, \mathrm{c}, *}$, Y. Sim Tang ${ }^{\mathrm{a}}$, Ulrike Dragosits ${ }^{\mathrm{a}}$, Chris R. Flechard ${ }^{\mathrm{b}}$, Paul Ward ${ }^{\mathrm{d}}$, Christine F. Braban ${ }^{\mathrm{a}}$ \\ ${ }^{a}$ Centre for Ecology \& Hydrology, Edinburgh Research Station, Penicuik, United Kingdom \\ b INRA, Agrocampus Ouest, UMR 1069 SAS, Rennes, France \\ ${ }^{\mathrm{C}}$ University of Edinburgh, School of Geosciences, Edinburgh, United Kingdom \\ ${ }^{\mathrm{d}}$ Cumbernauld, United Kingdom
}

\section{A R T I C L E I N F O}

\section{Article history:}

Received 8 February 2016

Revised 1 June 2016

Accepted 1 June 2016

Available online $\mathrm{xxxx}$

\section{Keywords:}

Anaerobic digestion

Ammonia emissions

Atmospheric dispersion modelling

Atmospheric concentration measurements

\begin{abstract}
A B S T R A C T
Anaerobic digestion (AD) is becoming increasingly implemented within organic waste treatment operations. The storage and processing of large volumes of organic wastes through $\mathrm{AD}$ has been identified as a significant source of ammonia $\left(\mathrm{NH}_{3}\right)$ emissions, however the totality of ammonia emissions from an $\mathrm{AD}$ plant have not been previously quantified. The emissions from an $\mathrm{AD}$ plant processing food waste were estimated through integrating ambient $\mathrm{NH}_{3}$ concentration measurements, atmospheric dispersion modelling, and comparison with published emission factors (EFs). Two dispersion models (ADMS and a backwards Lagrangian stochastic (bLS) model) were applied to calculate emission estimates. The bLS model (WindTrax) was used to back-calculate a total (top-down) emission rate for the AD plant from a point of continuous $\mathrm{NH}_{3}$ measurement downwind from the plant. The back-calculated emission rates were then input to the ADMS forward dispersion model to make predictions of air $\mathrm{NH}_{3}$ concentrations around the site, and evaluated against weekly passive sampler $\mathrm{NH}_{3}$ measurements.

As an alternative approach emission rates from individual sources within the plant were initially estimated by applying literature EFs to the available site parameters concerning the chemical composition of waste materials, room air concentrations, ventilation rates, etc. The individual emission rates were input to ADMS and later tuned by fitting the simulated ambient concentrations to the observed (passive sampler) concentration field, which gave an excellent match to measurements after an iterative process. The total emission from the AD plant thus estimated by a bottom-up approach was $16.8 \pm 1.8 \mathrm{mg} \mathrm{s}^{-1}$, which was significantly higher than the back-calculated top-down estimate $\left(7.4 \pm 0.78 \mathrm{mg} \mathrm{s}^{-1}\right)$. The bottom-up approach offered a more realistic treatment of the source distribution within the plant area, while the complexity of the site was not ideally suited to the bLS method, thus the bottom-up method is believed to give a better estimate of emissions. The storage of solid digestate and the aerobic treatment of liquid effluents at the site were the greatest sources of $\mathrm{NH}_{3}$ emissions.
\end{abstract}

(c) 2016 Elsevier Ltd. All rights reserved.

\section{Introduction}

Anaerobic Digestion (AD) is an organic waste treatment technology that is seen as a viable means to recover heat and electricity from organic waste streams such as animal slurry and food wastes (e.g. Wulf et al., 2006). During AD processing organic matter is microbially decomposed in the absence of oxygen to recover biogas and a nutrient-rich digestate which is often used as an organic fertiliser (Pain et al., 1990). The biogas (a mixture of approximately $2 / 3$ methane and $1 / 3$ carbon dioxide) produced can be sold as an

\footnotetext{
* Corresponding author at: INRA, Agrocampus Ouest, UMR 1069 SAS, Rennes, France.

E-mail address: Michael.Bell@rennes.inra.fr (M.W. Bell).
}

energy fuel or combusted on-site to produce renewable heat and/ or electricity.

AD has been developed to provide multiple environmental benefits in waste processing, including replacement of fossil fuels with biogas, diversion of waste from landfill, and the abatement of methane $\left(\mathrm{CH}_{4}\right)$ emissions from manure storage (Maranon et al., 2011). AD is becoming increasingly attractive for farmers and municipalities and is underpinned in national and international policy objectives (e.g. European Commission, 2009). Anaerobically digested manure is associated with a reduction in odours and pathogens (Chynoweth et al., 1999; Hansen et al., 2006), and also an increased fraction of plant-available ammonium and nitrate in the digestate itself (Möller and Stinner, 2009). Digestion typically causes an increase in $\mathrm{pH}$, thus digester effluents can be ideally suited to fertilise acid soils (Kvasauskas and Baltrenas, 2009). 
However, as the fraction of ammoniacal nitrogen is greater within the effluent mixture, there is a higher potential for $\mathrm{N}$ losses through ammonia $\left(\mathrm{NH}_{3}\right)$ volatilisation. Further, the elevated $\mathrm{pH}$ of digestate produces favourable thermodynamic conditions for the conversion of ammonium $\left(\mathrm{NH}_{4}^{+}\right)$to $\mathrm{NH}_{3}$ within solution, which increases $\mathrm{NH}_{3}$ emissions (Pain et al., 1990; Hansen et al., 2005). AD plants are generally centralised locations where organic wastes are delivered, stored and processed in high volume, concentrating distributed sources of $\mathrm{NH}_{3}$ emissions. Reduced nitrogen $\left(\mathrm{NH}_{\mathrm{x}}\right)$ has become one of the dominant atmospheric pollutants in Western Europe due to the significant decreases in sulphur emissions and significant decreases in nitrogen oxide emissions through the implementation of catalytic converters. Ammonia contributes to the acidification and eutrophication of ecosystems (e.g. Vestreng and Storen, 2000; Bobbink et al., 2010; Nihlgard, 1985; Draaijers et al., 1989) and formation of particulate matter (PM2.5), which is recognised to have an adverse effect on respiratory and cardiovascular health (Lillyman et al., 2009).

Emissions of $\mathrm{NH}_{3}$ in the UK (and worldwide) are generally dominated by the contribution from the agricultural sector (e.g. Misselbrook et al., 2000) originating from livestock housings, slurry stores, field application of organic manure and mineral fertilisers and grazing (Hill et al., 2008). Relative to unprocessed livestock manure, increased volatilisation of $\mathrm{NH}_{3}$ has been measured following the application of anaerobically digested manures to agricultural fields (Clemens et al., 2006; Pain et al., 1990). Studies concerning gaseous emissions from AD plants have so far mostly focussed on greenhouse gases (GHG), and in particular the abatement or release of methane (e.g. Møller et al., 2009; Flesch et al., 2011; Liebetrau et al., 2013). However $\mathrm{NH}_{3}$ emissions were measured from an $\mathrm{AD}$ plant in a life cycle analysis study carried out by Cumby et al. (2005). Fugitive emissions from the waste reception area were directly measured, but emissions from the storage of digestate were not measured. Clemens et al. (2006) investigated the treatment of animal slurries and co-digestion of mixed substrates through $\mathrm{AD}$, and found $\mathrm{NH}_{3}$ emissions from digested slurry to be twice as high as untreated slurry during a 140 day summer storage experiment.
Cumby et al. (2005) identified the key areas of $\mathrm{NH}_{3}$ emission from $\mathrm{AD}$ plants as: (a) the waste reception and pre-processing area, where the organic waste substrates are delivered and passed into the input stream, and (b) the digestate storage area, which holds the final product of the AD process (separated or unseparated) before further processing or use as biofertiliser. The scale of $\mathrm{NH}_{3}$ volatilisation is determined by environmental and substrate parameters including temperature, $\mathrm{pH}$, ventilation and ammoniacal N concentration (TAN) (e.g. Hansen et al., 2005). $\mathrm{NH}_{3}$ emissions are also dependent on site management practices concerning the handling, storage and treatment of organic wastes. For example, Whelan and Villa (2010) demonstrated in laboratory chamber experiments that $\mathrm{NH}_{3}$ emissions from food waste digestate could be limited by covering storage facilities and increasing the depth to surface ratio, (maintaining a high concentration of $\mathrm{NH}_{3}$ above the surface) despite an inherent propensity for volatilisation due to an elevated $\mathrm{pH}$ and $\mathrm{NH}_{3}: \mathrm{NH}_{4}^{+}$ratio.

In situ $\mathrm{NH}_{3}$ emissions from the whole of the $\mathrm{AD}$ plant site have not been previously measured, therefore through integrated atmospheric measurement and dispersion modelling methods the objectives of this study were to quantify and characterise the individual and overall sources of $\mathrm{NH}_{3}$ emissions at a food waste $\mathrm{AD}$ plant in central Scotland.

\section{Materials and methods}

\subsection{Site description}

The experiment took place from May-July 2014 at the Deerdykes AD plant, located near Cumbernauld $\left(55^{\circ} 55^{\prime} 28 \mathrm{~N}, 4^{\circ} 03^{\prime} 24 \mathrm{~W}\right)$, south of the Westfield Industrial Estate and approximately $250 \mathrm{~m}$ North of Mollinsburn. Constructed in 2010 , the plant processes about $30,000 \mathrm{t} \mathrm{yr}^{-1}$ of a mixture comingled green/catering wastes from municipal collections, biodegradable industrial sludges and Category 3 animal byproducts (animal materials with low-risk of infectious diseases). The AD plant comprises an inner concrete courtyard with several tall tanks and buildings (up to $6 \mathrm{~m}$ in height), (Figs. 1 and 2). At

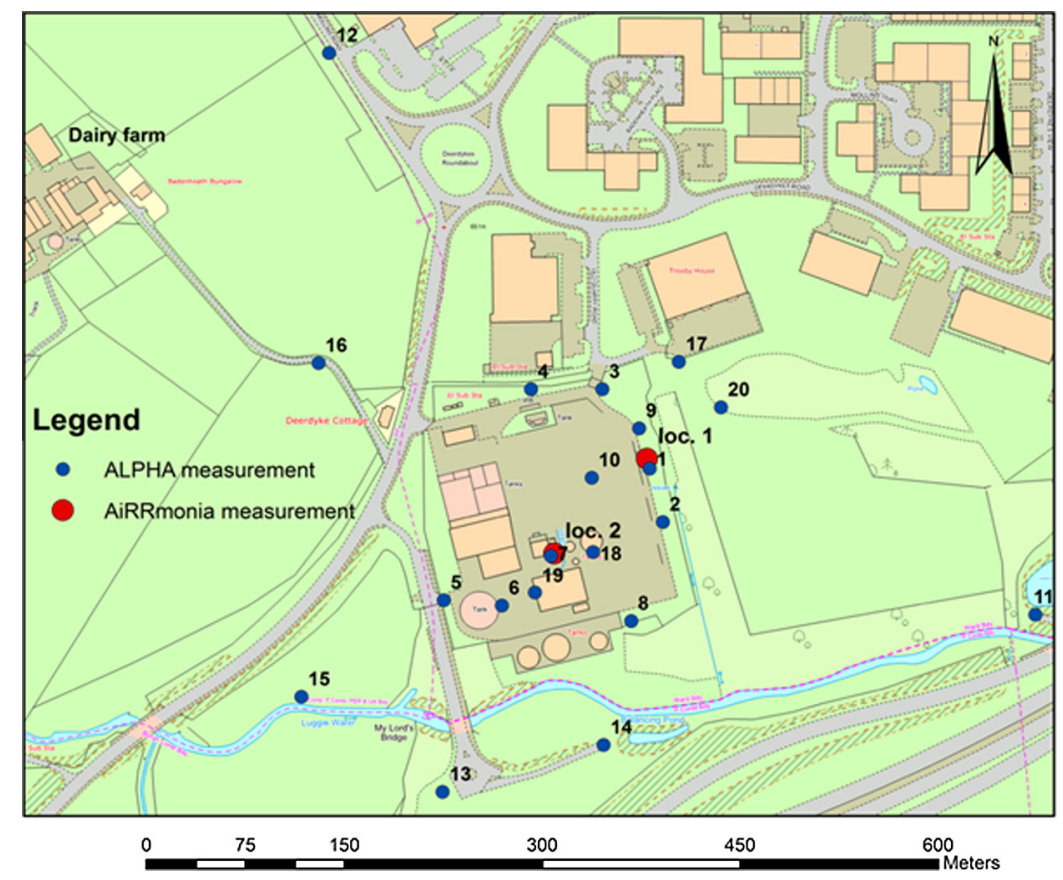

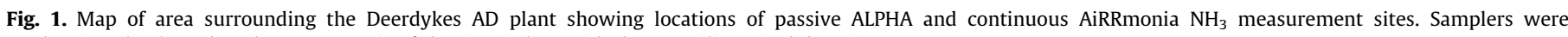
predominantly aligned to the SW-NE axis of the site, in line with the prevailing wind direction. 


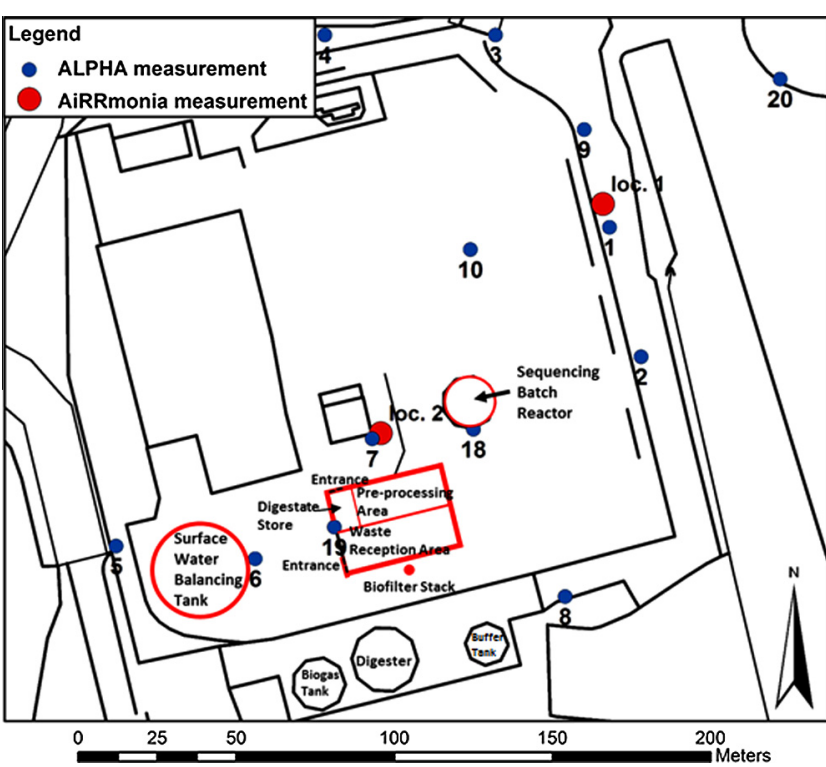

Fig. 2. Map of the central area at the Deerdykes $A D$ showing location of passive (ALPHA) and continuous (AiRRmonia) measurements and the key sources of $\mathrm{NH}_{3}$ (outlined in red). (For interpretation of the references to colour in this figure legend, the reader is referred to the web version of this article.)

the perimeter of the plant is a screening bund $2-3 \mathrm{~m}$ in height, partly surrounded by a tree belt and hedgerows with agricultural land, woodland and an industrial park beyond.

Wastes are delivered to the AD plant in both liquid and solid form, Fig. 3 summarises the processes and pathways for solid and liquid waste streams on the site. The solid wastes are delivered to the floor inside the waste reception area, and transferred to equipment that will shred and decontaminate the waste within an adjacent pre-processing area located within the same central waste reception building (WRB) (Fig. 3). Liquids and sludges are offloaded to a separate subterranean tank, before being pumped into the anaerobic digestion process via a buffer tank. Waste inputs are mixed with recycled, anaerobically treated and diluted process liquor to form a $15 \%$ dry matter slurry which is transferred into the $\mathrm{AD}$ unit operating within the mesophilic temperature range $\left(37^{\circ} \mathrm{C}\right)$ on a semi-continuous basis. The biogas released during $\mathrm{AD}$ (primarily methane and carbon dioxide) is withdrawn from the digester headspace and combusted on-site to recover electricity. The digested sludge (digestate) displaced from the bioreactor is dewatered and separated into liquid and solid fractions. Solids are stored within the digestate storage section of the WRB before agricultural use as biofertiliser. The liquor expressed from the sludge that isn't recycled to the AD unit is sent for treatment within a large sequencing batch reactor (SBR), before discharge to sewer. A multi-stage process creates the aerobic and anaerobic conditions needed to induce nitrification and denitrification, converting ammoniacal nitrogen to nitrite and nitrate and further reducing residual biological oxygen demand.

Solid digestate at Deerdykes is stored in shallow, wide heaps within the digestate storage area, with an average depth $(z)$ of less than $1 \mathrm{~m}$. The store is not ventilated, and the entrance is only opened up approximately two to three times per week to extract the digestate. A loader transfers the digestate into a container for haulage off site. Within the digestate storage area, the digestate pile typically covers the floor area, which is $60 \mathrm{~m}^{2}$. However the surface of the digestate is not smooth; the surface area available for volatilisation was estimated to be increased by roughness by a factor of 5-10. The roughness factor(s) were applied to the source area to scale emissions accordingly in ADMS dispersion modelling.

Other components of the AD plant relevant to $\mathrm{NH}_{3}$ emissions include the Surface Water Balancing Tank (SWBT) which captures surface water runoff and spillages to mitigate pollution. The waste reception area and pre-processing area are located within mechanically ventilated sections of the WRB, where extracted room air is discharged via a biofilter system designed to limit emissions of odorous compounds. The digestate storage area of the WRB is not connected to the biofilter system.

\subsection{Ammonia measurements}

Three $\mathrm{NH}_{3}$ measurement techniques were applied: timeintegrated sampling with passive diffusion ALPHA (Adapted Low-cost Passive High Adsorption) samplers (Tang et al., 2001), continuous on-line $\mathrm{NH}_{3}$ analysis using a trace gas analyser (AiRRmonia, ECN, 2003, Mechatronics, NL) and instantaneous/snap measurements made with a portable $\mathrm{NH}_{3}$ gas analyser (Micro 5, www.calgarysense.com).

\subsubsection{Passive sampler measurements}

ALPHA samplers have been extensively used (UK National Ammonia Monitoring Network, Vogt et al., 2013; Theobald et al., 2013; Riddick et al., 2014), and performed well in intercomparison studies (Puchalski et al., 2011). Six ALPHA measurement periods in total were carried out at the site from $15 / 05 / 2014$ to $10 / 07 / 2014$. Sampler exposure durations ranged

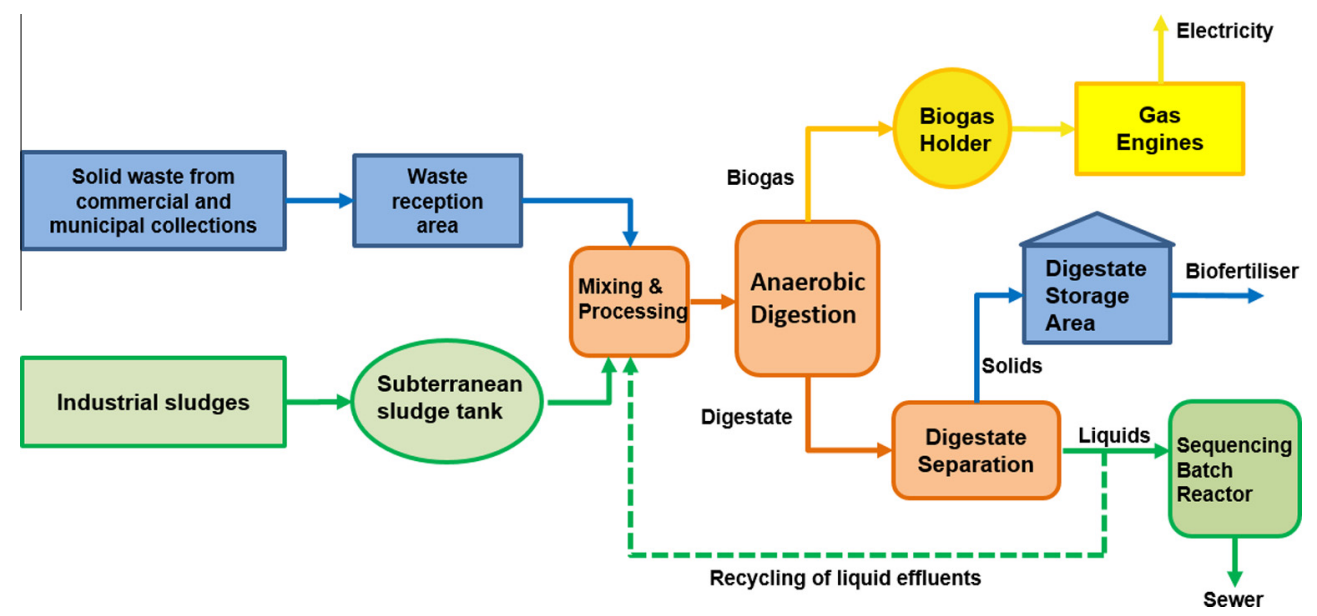

Fig. 3. Schematic diagram of pathways of solid and liquid wastes through AD plant. 
between 6 and 14 days. ALPHA samplers were deployed in triplicate at 20 locations across the site at a $1.5 \mathrm{~m}$ height (Fig. 1). Citric acid coated filter papers from the samplers were extracted in $3 \mathrm{ml}$ deionised water, and analysed for $\mathrm{NH}_{4}^{+}$by the AMmonium Flow Injection Analysis system (AMFIA) (Wyers et al., 1993). Laboratory blanks were subtracted from samples and field blanks were used to check for contamination.

\subsubsection{High temporal resolution continuous measurements}

On-line continuous $\mathrm{NH}_{3}$ concentration measurements were made with an AiRRmonia gas analyser. The continuous analyser was strategically deployed sequentially at two locations as shown in Fig. 2. The first measurement location, (28/05-26/06) was $100 \mathrm{~m}$ northwest of the $\mathrm{AD}$ plant along the axis of the prevailing wind direction (Loc. 1), while the second (27/06-16/07) was within the inner courtyard at the plant, $20 \mathrm{~m}$ from the entrance to the digestate store (Loc. 2). Air was sampled at a rate of $11 \mathrm{~min}^{-1}$ and $\mathrm{NH}_{3}$ diffused through a gas-permeable membrane into a stripping solution (converts $\mathrm{NH}_{3}$ to $\mathrm{NH}_{4}^{+}$ions). Ammonium ions passed through into a detector block through an ion-selective membrane where the conductivity was measured. Liquid phase calibration of the conductivity cell was carried out in the field every 6 days with 0 , 50 and $500 \mathrm{ppb} \mathrm{NH}_{4}^{+}$solutions and showed good stability over the periods of measurement. The AiRRmonia instrument was housed within a weather-proof container, where measurements were recorded every minute by the in-built datalogger, and later averaged at 10,30 and 60 min periods for analysis.

\subsubsection{Indoor $\mathrm{NH}_{3}$ measurements}

The gas alert Micro 5 portable multi-gas analyser was used to provide point measurements of room air concentrations inside the digestate store, preprocessing area and waste reception area at the site. By contrast to the ALPHA and AiRRmonia measurements in ambient outdoor air, the limit of detection for the Micro 5 device was much higher, of the order of $1 \mathrm{ppm}\left(0.7 \mathrm{mg} \mathrm{m}^{-3}\right)$, as opposed to roughly $0.1 \mu \mathrm{g} \mathrm{m}^{-3}$ for ALPHA and AiRRmonia measurements. Yet the Micro 5 was suitable for the task due to high indoor concentrations. Measurements were weekly, characterising the observed $\mathrm{NH}_{3}$ concentrations. It was not possible to install the Micro 5 due to lack of power outlets in the relevant buildings.

\subsection{Meteorological and ancillary measurements}

Standard meteorological measurements (wind speed, wind direction, temperature, relative humidity and rainfall) were provided by a citizen-operated local weather station in Cumbernauld (www.cumbernauld-weather.co.uk), located $1.6 \mathrm{~km}$ to the northeast of the site. These meteorological measurements were recorded by a Davis Vantage Pro2 system (www.davisnet.com). Cloud cover data, for use as a proxy atmospheric stability parameter with the ADMS meteorological pre-processor, was obtained from Glasgow Bishopton surface observation station which is $24 \mathrm{~km}$ from the site. The temperature was recorded inside the digestate store between 27/06/2014 and 06/07/2014 using a Tiny Tag data logger (www. geminidataloggers.com).

\subsection{Atmospheric modelling}

\subsubsection{Lagrangian stochastic (bLS) dispersion model}

The backward Langrangian stochastic (bLS) dispersion model "WindTrax", described in detail in Flesch et al. (2004) and available at www.thunderbeachscientific.com was used to infer the total emission from the AD plant. The basic WindTrax equations are summarised below. The model in this work was configured to release $5 \times 10^{4}$ "fluid particles" backwards from a concentration receptor, the fraction of which intersect the source area derives a dispersion coefficient $D$. This dispersion coefficient gives the flux of $\mathrm{NH}_{3}$ emitted from the source, $\left(Q, \mu \mathrm{g} \mathrm{m}^{-2} \mathrm{~s}^{-1}\right)$ using the measured rise in concentration $C$ above background $C_{b}$ (in $\mu \mathrm{g} \mathrm{m}^{-3}$ ), by the relationship:

$Q=\left(C-C_{b}\right) * D$

where $D$ is retrieved by the model as the number of source area interactions $\left(N_{\text {source }}\right)$ and the thousands of trajectories $(N)$ generated by the model from the receptor locations, along with the associated vertical velocity of each interaction $\left(w_{o}\right)$ (see Eq. (2), and details in Flesch et al., 2004).

$D=\frac{1}{N} \sum N_{\text {source }}\left|\frac{2}{w_{o}}\right|$

Continuous $\mathrm{NH}_{3}$ concentration data from the AiRRmonia measurements were averaged over $1 \mathrm{~h}$ periods. The AiRRmonia and meteorological data were filtered to measurements where the AD plant was directly upwind of the AiRRmonia gas analyser (wind direction $210-235^{\circ}$ ). This was sufficient so that at least $50 \%$ of the calculated plume trajectories covered the emission area. The input data was also filtered to remove calibration periods and known conditions where the inverse dispersion model is known to become inaccurate (Flesch et al., 2005). These conditions included low winds (where frictional velocity $\left(\mu^{*}\right)$ was less than $0.15 \mathrm{~m} \mathrm{~s}^{-1}$ ) and strongly stable/unstable atmospheric stratification $(L<10 \mathrm{~m})$.

Standard hourly meteorological measurements were input to WindTrax for the first measurement period (28/05-26/06). Including the following variables: $\mathrm{NH}_{3}$ concentration at $2 \mathrm{~m}$ height $(\mathrm{C} \mu \mathrm{g} /$ $\left.\mathrm{m}^{3}\right)$, background concentration $\left(C_{b} \mu \mathrm{g} \mathrm{m}^{-3}\right)$, wind speed $\left(\mu, \mathrm{m} \mathrm{s}^{-1}\right)$, wind direction (WD, $\left.{ }^{\circ}\right)$, and ADMS-calculated Monin-Obukhov length $(L)$. To determine a background concentration $\left(C_{b}\right)$ for the site, the AiRRmonia concentration measurements were filtered to strictly upwind $\left(320-180^{\circ}\right)$ periods. The model retrieved emission estimates from the $\mathrm{AD}$ plant for each 60 min timestep satisfying the measurement criteria, relying on the assumption that the downwind concentrations are directly proportional to the source emission rate. Thus for a perfect dispersion model under homogeneous conditions the real emission rate can be derived from the simulated concentration $\left(C_{\text {sim }}\right)$ using the emission rate $Q_{\text {sim }}$ (Eq. (3)).

$Q=\frac{\left(C-C_{b}\right)}{(C / Q)_{s i m}}$

The Deerdykes AD facility presents complications for inverse dispersion calculations. Buildings and structures generate complex wind movements, and the relative intensity of all the emission sources is unknown. However studies using the inverse dispersion method have demonstrated insensitivity to these complications if measurements are taken far enough downwind (Flesch et al., 2005, 2011; McGinn et al., 2006). Two criteria are proposed by Flesch et al. (2005): (1) the downwind distance of the concentration sensor should be a minimum of ten times the height of the largest wind obstacle, and (2) roughly two times the maximum distance between potential sources. The Deerdykes facility meets the first criterion (waste reception building height is $6.4 \mathrm{~m}$, distance to nearest source is $70 \mathrm{~m}$ ) but not the second (distance between SWBT and SBR is $80 \mathrm{~m}$ ). Therefore for intercomparison a second dispersion modelling method has been applied to estimate emissions.

\subsubsection{ADMS dispersion modelling}

Source strengths may be determined by assigning an arbitrary emission rate to a dispersion model and scaling the modelled concentrations to the measured values (above background) by 
Table 1

ADMS model inputs.

\begin{tabular}{|c|c|c|c|}
\hline Variable & Units & Configuration/parameterisation & Value \\
\hline Wind speed & $\mathrm{m} \mathrm{s}^{-1}$ & Building configuration & - \\
\hline Wind direction & $\circ$ & Grid area (10 m spaced) & $900 \times 700 \mathrm{~m}$ \\
\hline Rain & $\mathrm{mm} \mathrm{h}^{-1}$ & Passive sampler locations & - \\
\hline Temperature & ${ }^{\circ} \mathrm{C}$ & Surface roughness $\left(\mathrm{z}_{0}\right)^{\mathrm{a}}$ & $0.2-1 \mathrm{~m}$ \\
\hline Relative humidity & $\%$ & Dry deposition rate ${ }^{\mathrm{b}}$ & $0.02 \mathrm{~m} \mathrm{~s}^{-1}$ \\
\hline Cloud cover & Oktas (8ths) & Washout coefficient ${ }^{\mathrm{C}}$ & $9 \times 10^{-6} s^{-1}$ \\
\hline
\end{tabular}

a Gridded surface roughness file.

b Environment Agency (2010).

c CLAG (1994).

applying a correction factor (e.g. Hill et al., 2008; Faulkner et al., 2007; Theobald et al., 2013). A variant of this technique was applied with the Atmospheric Dispersion Modelling System (ADMS) (Carruthers et al., 1994). ADMS is an "advanced generation" Gaussian dispersion model, modified from the basic Gaussian equation to take into account vertical profiles of boundary layer parameters and continuous stability functions (Holmes and Morawska, 2006). These modifications lead to improved predictions of vertical and horizontal concentration distribution profiles under a range of stability conditions (Theobald et al., 2012). The ADMS-Urban version used also features a complex terrain module which can accommodate for a domain of variable roughness lengths $\left(\mathrm{z}_{0}\right)$, and include the dimensions of individual buildings to simulate concentrations where there are building effects. The ADMS model was configured with the input data listed in Table 1.

\subsubsection{Modelling scenarios}

The objective of the modelling scenarios was to test different source area treatments and modelling methods, and evaluate predictions against passive sampler measurements. Three scenarios were set up to investigate and evaluate different emissions estimates for the AD plant. A key objective was to find an emission estimate (model + emission inventory) that performs well in reproducing observed concentrations but also finds a balance with the conceptual model of emissions from the AD, arguments for which are developed from on-site investigations and published emission factors. All of the scenarios used the ADMS forward dispersion model to predict the long-term average concentrations across a $900 \times 700 \mathrm{~m}$ model domain at a $10 \times 10 \mathrm{~m}$ resolution. Each scenario used the meteorological data (inputs) and ALPHA NH $\mathrm{N}_{3}$ concentration measurements (verification data) corresponding to four sets of weekly ALPHA measurements (28/05-26/06).

Scenarios included:

(1) Top-down emission estimate of total emissions by bLS method, assuming homogeneous source area.

(2) Bottom-up estimates of individually defined sources, determined using theoretical methods and the available AD plant parameters. These include: published emission factors from the literature, room air concentration measurements (Micro 5 ), site parameters such as biofilter air flow rate and estimated scrubbing efficiency, chemical analysis of solid and liquid effluents obtained from the AD plant and assumptions regarding the ventilation rate of buildings.

(3) Optimised emission rates were derived following iteration of individual emission estimates (Scenario 2) to match simulated concentrations with ALPHA measurements, whilst taking into account site parameters.

\subsubsection{Model performance evaluation}

Evaluation of model performance requires a statistical comparison of concentration predictions $\left(C_{p}\right)$ with observed values $\left(C_{o}\right)$. To evaluate ADMS predictions against ALPHA measurements for each scenario, the five performance measures suggested by Chang and Hanna (2004) are used:

Fractional bias : $\mathrm{FB}=\frac{2\left(\overline{C_{o}}-\overline{C_{p}}\right)}{\left(\overline{C_{o}}+\overline{C_{p}}\right)}$

Geometric mean bias : $\mathrm{MG}=\exp \left(\overline{\ln C_{o}}-\overline{\ln C_{p}}\right)$

Normalised mean square error : NMSE $=\frac{\overline{\left(C_{o}-C_{p}\right)^{2}}}{\overline{C_{0} C_{p}}}$

Geometric variance : $\mathrm{VG}=\exp \left[\overline{\left(\ln C_{o}-\ln C_{p}\right)^{2}}\right]$

FAC2 $=$ fraction of data that satisfy : $0.5 \leqslant \frac{C_{p}}{C_{0}} \leqslant 2$

Note overbars denote the mean of each dataset.

The NMSE, VG and FAC2 are composite measures that take into account the both bias and scatter in the predicted values relative to the observations, while the FB and MG are measures of model bias and describe the tendency of the model to over or under-predict observed concentrations. Chang and Hanna (2004) have suggested ranges for the five performance indices that indicate acceptable model performance. The ranges suggested are: $\mathrm{FB}<0.3, \quad 0.7<\mathrm{MG}<1.3, \quad \mathrm{NMSE}<1.5, \quad \mathrm{VG}<4$ and FAC2 $>50 \%$.

\subsection{Theoretical estimation of emissions based on site parameters}

Chemical analysis of digestion substrates and digestate is routinely carried out at various stages of the $\mathrm{AD}$ process by the plant operators. Some of these data $\left(\mathrm{NH}_{4}-\mathrm{N}\right.$ content, $\left.\mathrm{pH}\right)$ were made available for the estimation of emissions, by applying to EFs within the literature along with other operational parameters such as ventilation rates, surface areas, and indoor room air concentration measurements made with the Micro 5.

Empirical relationships based upon the regression of $\mathrm{NH}_{3}$ emissions against influencing parameters such as temperature, $\mathrm{NH}_{4}-\mathrm{N}$ content, $\mathrm{pH}$ and air ventilation rates can give default predictions of $\mathrm{NH}_{3}$ emission rates when limited parameters are available for calculation (e.g. Jarvis, 1993; Ross et al., 2002). The model of Borka et al. (2000) describes the emissions of $\mathrm{NH}_{3}\left(\mathrm{E}, \mathrm{mg} \mathrm{m}^{-2} \mathrm{~h}^{-1}\right.$ ) from manure in livestock buildings, and was developed from the regression of substrate temperature $\left(\mathrm{TS},{ }^{\circ} \mathrm{C}\right)$, air exchange rate (LD, $\mathrm{m}^{3} \mathrm{~h}^{-1} \mathrm{~m}^{-2}$ ), and $\mathrm{NH}_{4}-\mathrm{N}$ content (TAN, $\mathrm{g} \mathrm{N} \mathrm{kg}^{-1}$ ) (Eq. (9)), in controlled experiments within respiration chambers. This emission model has been applied to estimate emissions from the storage of solid fraction digestate at Deerdykes.

$\mathrm{E}=17.254 * 1.060^{\mathrm{TS}} * \mathrm{LD}^{0.274} * \mathrm{TAN}$ 


\section{Results}

A summary of the $\mathrm{NH}_{3}$ measurements taken at the site is hereafter presented. The $\mathrm{NH}_{3}$ measurements include firstly those taken with the AiRRmonia gas analyser, which initially was placed $100 \mathrm{~m}$ $\mathrm{NE}$ of the AD plant to operate nearly continuously from (28/05 to 26/06). The second period of continuous measurement placed the AiRRmonia analyser outside of the digestate storage area, which was expected to be the major source of $\mathrm{NH}_{3}$ at the site. The following section summarises the $\mathrm{NH}_{3}$ concentration distribution as measured by the weekly sampling network of ALPHA samplers placed at 20 locations around the site. Last of the measurements, the chemical properties of waste materials and estimates of emissions after applying literature EFs are given. The modelling results follow, including the evaluation of emission estimates (Scenario 1, 2 \& 3) with ALPHA concentration measurements.

\subsection{Continuous measurements}

During the first continuous measurement period the AiRRmonia analyser was placed at Location $1,100 \mathrm{~m} \mathrm{NE}$ of the AD plant and inline with the prevailing SW wind direction (Fig. 5). Ammonia concentrations fluctuated with changes in wind direction, with the highest concentrations measured during SW wind directions when the AiRRmonia was downwind of the AD plant (Figs. 4 and 6). The mean measured air $\mathrm{NH}_{3}$ concentration at this location from 28/05 to $26 / 06$ was $4 \mu \mathrm{g} \mathrm{m}^{-3}$. Filtering the AiRRmonia data measurements to periods where the AiRRmonia sensor was directly downwind of the central area of the AD plant (WD 210-235', WS $>1 \mathrm{~m} \mathrm{~s}^{-1}$ ) gave an average concentration $C$ of $6.5 \mu \mathrm{g} \mathrm{m}^{-3}$. The background concentration $\left(C_{b}\right)$, approximated by filtering measurements to periods where the AiRRmonia sensor was upwind of the AD plant (310-180 ), was $1.8 \mu \mathrm{g} \mathrm{m}^{-3}$ (Table 2 ).

During the second period of AiRRmonia continuous air $\mathrm{NH}_{3}$ concentration measurement, the instrument was placed to the north of the waste reception building at ALPHA site 7, $20 \mathrm{~m}$ from the entrance to the digestate store. The $\mathrm{NH}_{3}$ concentration time series during this period (27/07-16/07) is characterised by a relatively low baseline $\left(<10 \mu \mathrm{g} \mathrm{m}^{-3}\right)$ with high-concentration events occur-

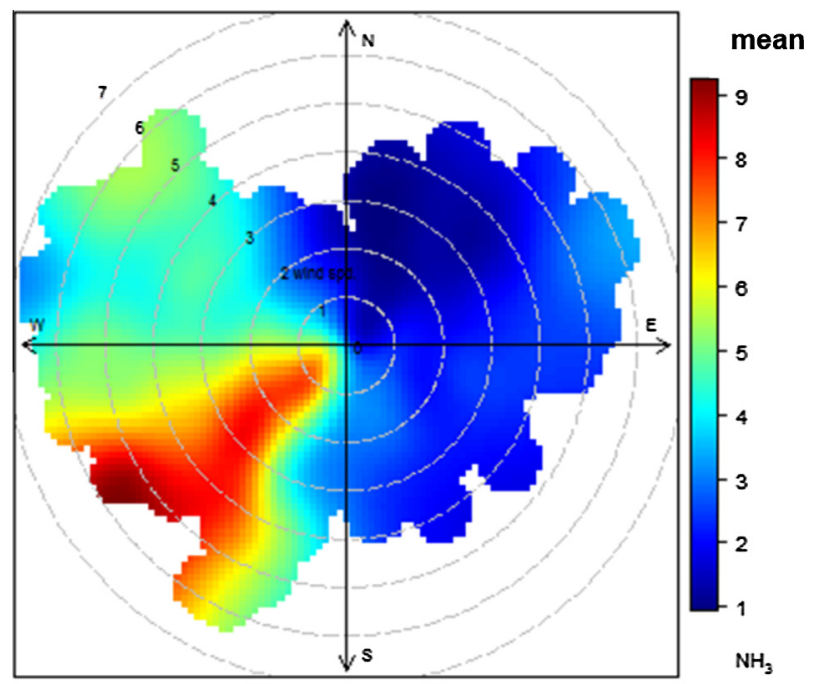

$\left(\mu \mathrm{g} \mathrm{m}^{-3}\right)$

Fig. 4. Polarplot of AiRRmonia concentration measurements with wind speed and direction for AiRRmonia Period 1, (28th May-26th June). Averaging period is $10 \mathrm{~min}$. Wind speed and direction data supplied by www.cumbernauld-weather.co. uk, plotted using the OpenAir package (Carslaw and Ropkins, 2012).

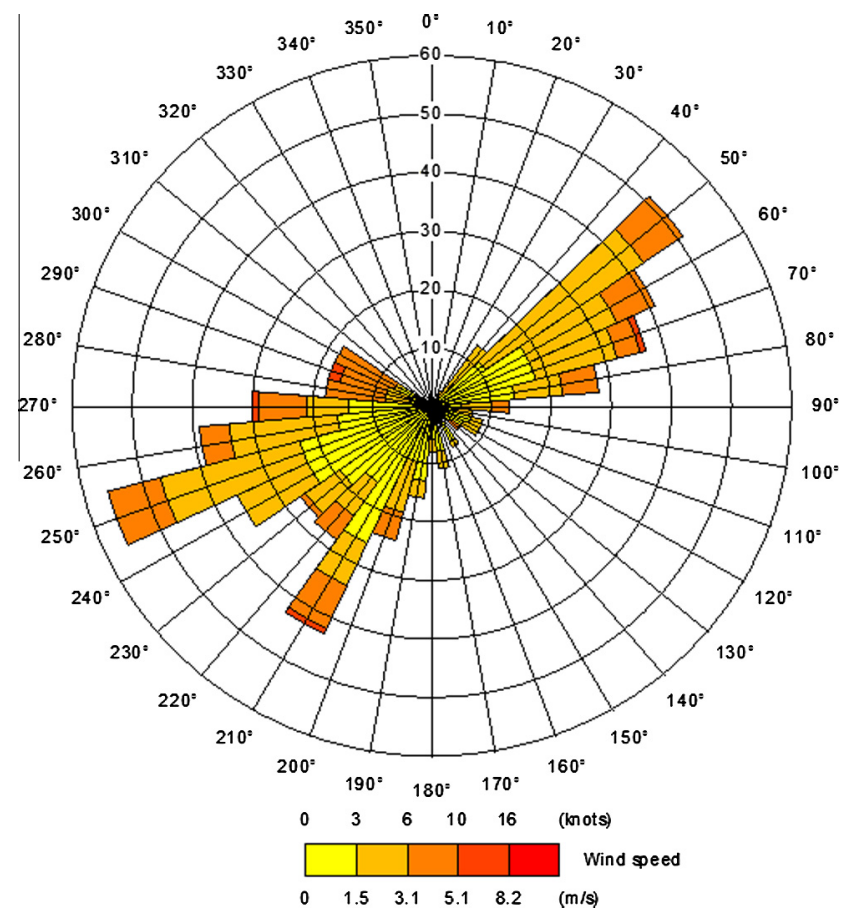

Fig. 5. Windrose of meteorological data from the 28th May to the 26th June. Averaging period is $1 \mathrm{~h}$. Plotted using the ADMS met. data processor.

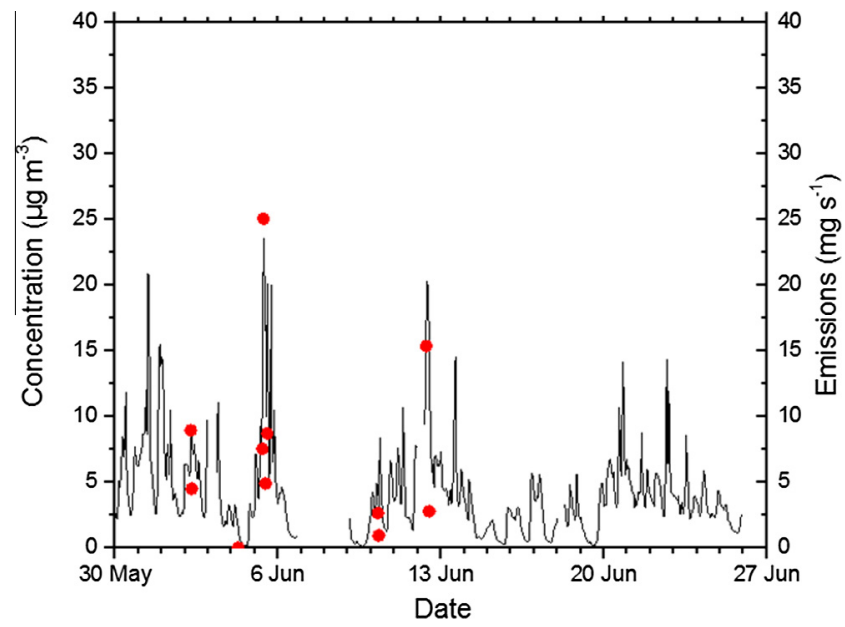

Fig. 6. Time series of AiRRmonia continuous air $\mathrm{NH}_{3}$ measurements (black line) and bLS emissions estimates (red points), AiRRmonia Period 1, location 1 (28th May26th June). Daily averaged wind direction arrows are annotated above (direction wind is coming from). (For interpretation of the references to colour in this figure legend, the reader is referred to the web version of this article.)

ring every 2-6 days, where air concentration would rise up to $300 \mu \mathrm{g} \mathrm{m}^{-3}$ and return back to baseline level within a few hours (Fig. 7). Emissions from the digestate store are expected to be episodic as high concentrations accumulate inside and are released as the store is opened and the digestate is extracted. This occurred roughly three times per week (but exact days/times were not recorded by the plant operators), which is consistent with the number of emission events that occurred over the monitoring period. Therefore the digestate store door is a dominating source of emissions at this location which should be individually defined for dispersion modelling. 
Table 2

Average downwind and background $\mathrm{NH}_{3}$ concentration measurements, AiRRmonia Period 1 (28th May-26th June), and average WindTrax emission rate calculations.

\begin{tabular}{|c|c|c|c|c|c|c|}
\hline & \multicolumn{3}{|c|}{$\begin{array}{l}\text { AiRRmonia averaged concentration per } \\
\text { wind sector }\left(\mu \mathrm{g} \mathrm{NH}_{3} \mathrm{~m}^{-3}\right)\end{array}$} & \multicolumn{3}{|c|}{ Average emission rate $\left(\mathrm{mg} \mathrm{NH}_{3} \mathrm{~s}^{-1}\right)^{\mathrm{a}}$} \\
\hline & $\begin{array}{l}\text { All wind } \\
\text { sectors }\end{array}$ & $210-235^{\circ}$ & $310-180^{\circ}$ & $\begin{array}{l}\text { Background } \\
\text { concentration: } 0.43 \mu \mathrm{g} \mathrm{m}^{-3}\end{array}$ & $\begin{array}{l}\text { Background } \\
\text { concentration: } 1.8 \mu \mathrm{g} \mathrm{m}^{-3}\end{array}$ & $\begin{array}{l}\text { Background } \\
\text { concentration: } 3.17 \mu \mathrm{g} \mathrm{m}^{-3}\end{array}$ \\
\hline Average & 4 & 6.5 & 1.8 & 8.4 & 7.4 & 6.3 \\
\hline Standard deviation & 3.1 & 4.9 & 1.4 & 7.2 & 7 & 7.2 \\
\hline
\end{tabular}

a Averaged bLS estimate calculated from continuous AiRRmonia measurements, filtered to the downwind $\left(210-235^{\circ}\right)$ wind sector and meteorological criteria. Averaged emissions are calculated for the mean background concentration (310-180 wind sector) and to one standard deviation above and below the mean.

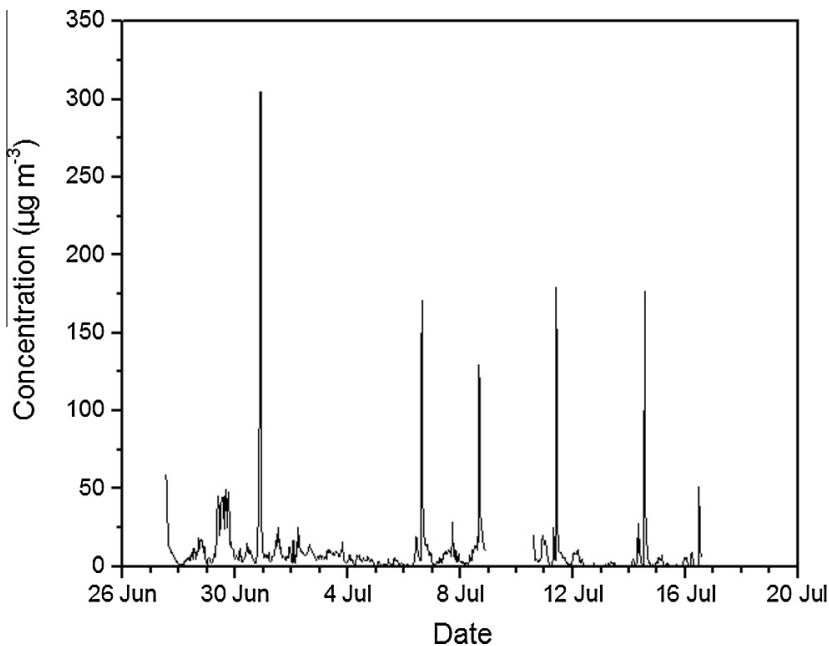

Fig. 7. Timeseries of AiRRmonia-measured $\mathrm{NH}_{3}$ concentrations at Location 2, outside of digestate store.

\subsection{Passive measurements}

Of the 20 sampling locations across the site, the highest weekly mean concentrations $\left(6-20 \mu \mathrm{g} \mathrm{m}^{-3}\right.$ ) occurred near the central WRB at the AD plant, showing strong temporal variation between measurements (Supplementary material). The WRB is a compartmentalised space containing the digestate storage, waste reception and waste pre-processing areas. A strong decrease in concentration occurred with increasing distance from the plant, with background concentrations $\left(1.5 \mu \mathrm{g} \mathrm{m}^{-3}\right.$ ) found nearby $(200 \mathrm{~m})$, depending on the prevailing wind direction and the presence of hedge effects.

\subsection{Theoretical emissions estimates}

In reviewing the chemical analysis of the solid fraction digestate, there is a substantially higher Total Kjeldahl Nitrogen (TKN) and $\mathrm{NH}_{4}-\mathrm{N}$ content than the literature values given, therefore more $\mathrm{NH}_{3}$ should be available to volatilise thermodynamically (provided substrate $\mathrm{pH}$ is similar) (Table 3 ). Digestate store emission rates for air exchange rates of $0.5,1$ and $1.5 \mathrm{~m}^{3} \mathrm{~h}^{-1} \mathrm{~m}^{-2}$ were calculated using Eq. (9), which compares well to the literature values given. The temperature within the digestate store displayed strong diurnal variations, with temperatures ranging from 10 to $25^{\circ} \mathrm{C}$ nightday. The average air temperature $\left(16.4^{\circ} \mathrm{C}\right)$ was assumed to be equal to the average surface temperature of the digestate.

Emissions of $\mathrm{NH}_{3}$ from the SBR, SWBT, the waste reception area, pre-processing area and biofilter stack are derived from emission measurements in the literature (Cumby et al., 2005; Borka et al., 2000; Willers et al., 1996; Leytem et al., 2010). These EFs are applied to the AD plant and presented in Table 4, using the available Deerdykes operational specifications, chemical measurements, and Gas-Micro-5 room air concentration measurements.

\subsection{Inverse and forward dispersion modelling}

\subsection{1. bLS estimate of emissions}

The WindTrax model treated the emissions from the AD plant as three homogeneous area sources that are marked by the boundaries of the WRB, SWBT \& SBR $\left(1000,700 \& 150 \mathrm{~m}^{2}\right.$ respectively, Fig. 2), which were identified as likely to be the main source areas. After filtering to the meteorological criteria set out in Section 2.4.1 only $11 / 690$ hourly measurements are suitable for estimating emissions by the bLS method. From the remaining emission estimates, an important feature is the apparent temporal variation in strength of emissions, with a range of $0-25 \mathrm{mg} \mathrm{s}^{-1}$ (Fig. 6).

Table 3

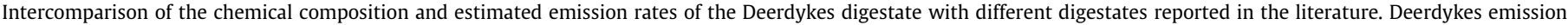
rates are calculated using the Borka et al. (2000) model.

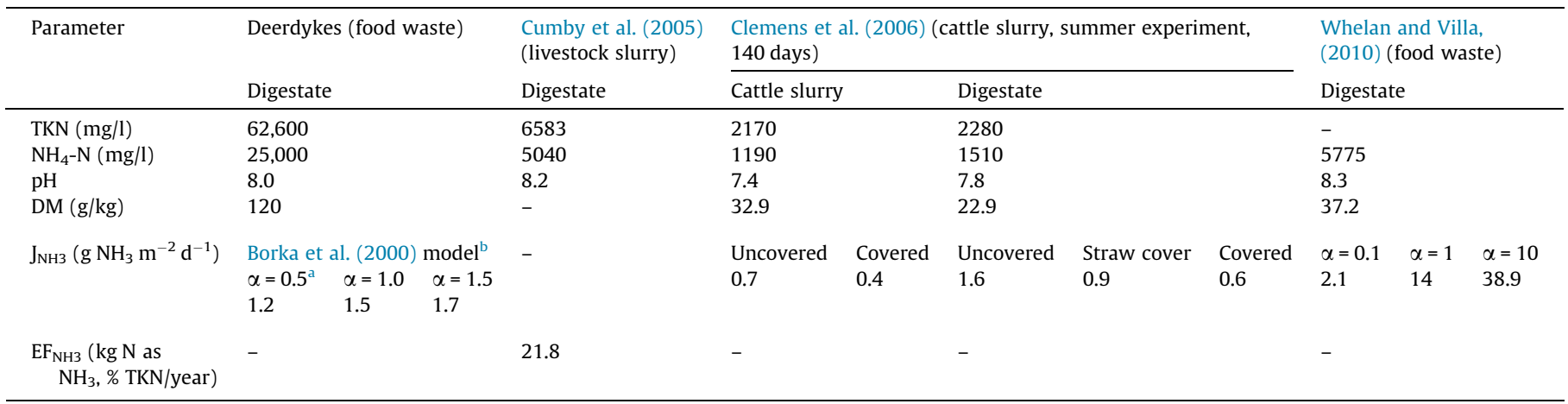

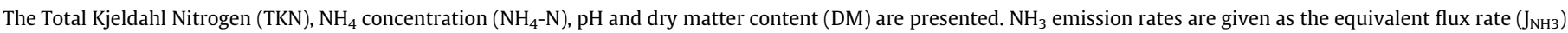
and the yearly emission factor $\left(\mathrm{EF}_{\mathrm{NH} 3}\right)$.

${ }^{a} \alpha$ is the ventilation rate (air changes per hour).

b Deerdykes equivalent fluxes calculated from the empirical model of Borka et al. (2000), Eq. (9). Where: TS = 16.4, LD = 0.5, 1.0, 1.5, TAN = 20.5. 
Table 4

Initial (literature EF-based) and optimised (fitted to ambient concentration measurements) $\mathrm{NH}_{3}$ emission rates calculated for individual sources within $\mathrm{AD}$ plant.

\begin{tabular}{|c|c|c|c|c|c|c|}
\hline Source name & Type & Emission factor & Intensity & $\begin{array}{l}\text { Scenario } 2 \text { : initial area-integrated } \\
\text { emission rate }\left(\mathrm{mg} \mathrm{s}^{-1}\right)\end{array}$ & $\begin{array}{l}\text { Scenario } 3 \text { : optimised } \\
\text { emission rate }\left(\mathrm{mg} \mathrm{s}^{-1}\right)\end{array}$ & Reference \\
\hline Digestate store & Point & $17.4 \mu \mathrm{g} \mathrm{m}^{-2} \mathrm{~s}^{-1}$ & $60 \mathrm{~m}^{\mathrm{b}} \times 5$ & 5.2 & 7.3 & Borka et al. $(2000)^{a}$ \\
\hline Biofilter & Point & $465 \mu \mathrm{g} \mathrm{s}^{-1}$ & 1 & 0.5 & 0.5 & Cumby et al. $(2005)^{\mathrm{b}}$ \\
\hline Waste reception area door & Point & $1020 \mu \mathrm{g} \mathrm{s}^{-1}$ & 1 & 1 & 0.1 & Cumby et al. $(2005)^{c}$ \\
\hline Pre-processing area & Line & $41.5 \mu \mathrm{g} \mathrm{m}^{-1} \mathrm{~s}^{-1}$ & $31 \mathrm{~m}$ & 1.3 & 0.6 & Cumby et al. $(2005)^{d}$ \\
\hline Sequencing batch reactor & Point & $61.1 \mu \mathrm{g} \mathrm{m}^{-2} \mathrm{~s}^{-1}$ & $200 \mathrm{~m}^{\mathrm{b}} \times(10 / 24)$ & 5.1 & 5.1 & Willers et al. $(1996)^{\mathrm{e}}$ \\
\hline Surface Water Balancing Tank & Area & $23.4 \mu \mathrm{g} \mathrm{m}^{-2} \mathrm{~s}^{-1}$ & $616 \mathrm{~m}^{\mathrm{b}}$ & 14.4 & 3.2 & Leytem et al. $(2010)^{\mathrm{f}}$ \\
\hline Total emissions & & & & 27.5 & 16.8 & \\
\hline
\end{tabular}

a Eq. (9): assumed ventilation rate is 1.0 air changes per hour. Surface roughness factor is estimated to be 5 .

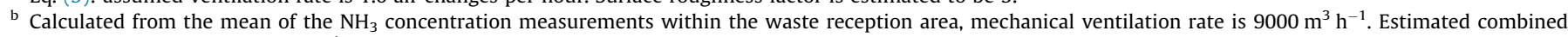
room air concentration is $1.43 \mathrm{mg} \mathrm{s}^{-1}$. Biofilter $\mathrm{NH}_{3}$ scrubbing efficiency is taken to be $87 \%$ as measured in the experiments of Cumby et al. (2005).

c Based on the assumption that $50 \%$ of air exchange occurs through direct discharge (Cumby et al., 2005), and that the large door to the waste reception area on the west side of the building is the only outlet. Measured room air concentration is $0.75 \mathrm{mg} \mathrm{m}^{-3}$.

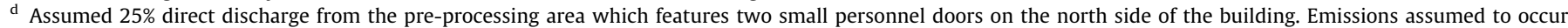
evenly across this surface. Measured room air concentration: $2.25 \mathrm{mg} \mathrm{m}^{-3}$.

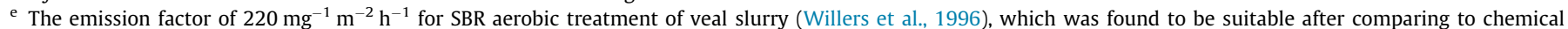
analysis of Deerdykes SBR liquid. The authors reported that this was the average emission over the course of a daily $22 \mathrm{~h}$ aeration cycle.

${ }^{\mathrm{f}}$ Flesch et al. (2009) and Leytem et al. (2010) published emission rates from dairy farm wastewater lagoons in the U.S., the lower estimate of the two (2.02 $\mathrm{g} \mathrm{m}^{-2} \mathrm{~d}^{-1}$, Leytem et al., 2010) was selected for the SWBT at Deerdykes.

Therefore there were periods where the analyser was directly downwind from the AD plant yet the measured concentration showed no rise above background, which suggests that emissions occur in events, such as delivery and removal of waste materials at the site, or aerobic denitrification cycles starting within the SBR for effluent treatment.

The average emission rate was $7.4 \mathrm{mg} \mathrm{s}^{-1}$ or $3.9 \mu \mathrm{g} \mathrm{m}^{-2} \mathrm{~s}^{-1}$ (total source area $1875 \mathrm{~m}^{2}$ ), (Table 2). Despite the apparent variation in emissions at the site, it is necessary to set the plant emission rate as a single average value to evaluate the bLS emissions estimate against the long-term passive sampler observations. The small number of emission estimates has a high standard deviation of $6.98 \mathrm{mg} \mathrm{s}^{-1}$. This averaged figure therefore may not be representative of the true averaged emission rate with such a small sample. Further consideration must also be given to the background concentration, its variability and the sensitivity of emission estimates to different selections. The average background concentration $\left(C_{b}\right)$, after filtering measurements to the $320-180^{\circ}$ wind direction, was $1.8 \mu \mathrm{g} \mathrm{m}^{-2} \mathrm{~s}^{-1}$. Emissions from the plant were also estimated using background concentrations set to one standard deviation above and below the average $C_{b}$, which gave a range of averaged emission estimates of $6.4-8.4 \mathrm{mg} \mathrm{s}^{-1}$ (Table 2).

\subsubsection{Evaluation of Scenario 1: bLS emissions estimates}

The Scenario 1-simulated concentrations are generally lower than ALPHA measurements, with a regression of 0.68 (Fig. 8), indicating that this estimate is likely lower than the true averaged emission strength from the plant. There is a poorer fit near to the central area sources where concentrations are highest. WindTrax assumes that emissions are homogeneously distributed within the source area, which is not a realistic treatment and increases the degree of error in predicted concentrations around the central area. With increasing distance downwind, concentration predictions have a greater accuracy, in-line with a distance-related insensitivity to similar complications reported by Flesch et al. (2005, 2011).

\subsubsection{ADMS modelling of $\mathrm{NH}_{3}$ concentrations after differentiation of} model into multiple sources: Scenario 2-3

Six discrete sources were input to the model to replace the homogenous area sources, with the aim to provide alternative estimates for total plant emissions, and to investigate emissions from individual sources and simulate $\mathrm{NH}_{3}$ concentrations near the

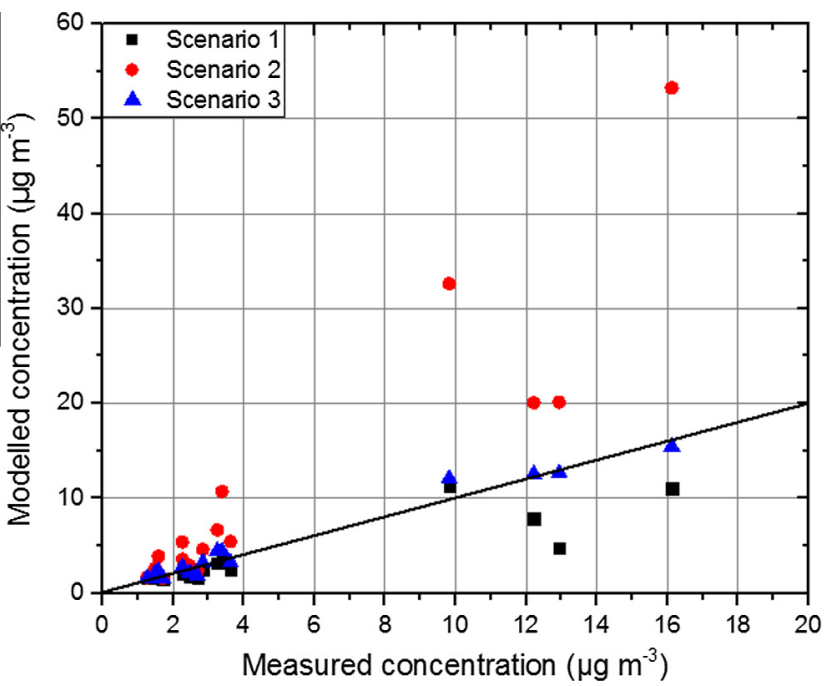

Fig. 8. Scatter plot of measured and ADMS-predicted $\mathrm{NH}_{3}$ concentrations at ALPHA receptors, comparing model Scenarios 1,2 \& 3 .

source area. Scenario 2 emission rates for each source were estimated by the theoretical methodology outlined in Section 2.4 (Table 4).

Overall, through optimisation the Scenario 3 total emissions from the plant were reduced to $16.8 \mathrm{mg} \mathrm{s}^{-1}$, from the (theorybased) Scenario 2 estimate of $27.5 \mathrm{mg} \mathrm{s}^{-1}$. Scenario 2-predicted concentrations at the passive receptors were higher by a factor of $\sim 2.4$ on average than the ammonia measured with ALPHA samplers (Fig. 8). In particular, the ADMS concentrations around the SWBT were much higher than the ALPHA measurements, with concentrations at site 5, 6 and 19 all exceeding measured concentrations by factors of $\sim 3.2$. The SWBT emission rate in the model leads to an overestimation of concentrations therefore the model was optimised using a factor to fit to observations. It was found that an optimisation factor of 0.22 best replicated the average concentration around the SWBT. Further optimisation factors were applied to the digestate store (1.4), the waste reception area door (0.06), and the pre-processing area line source $(0.5)$ to fit the predicted concentrations against the ALPHA measurements. 


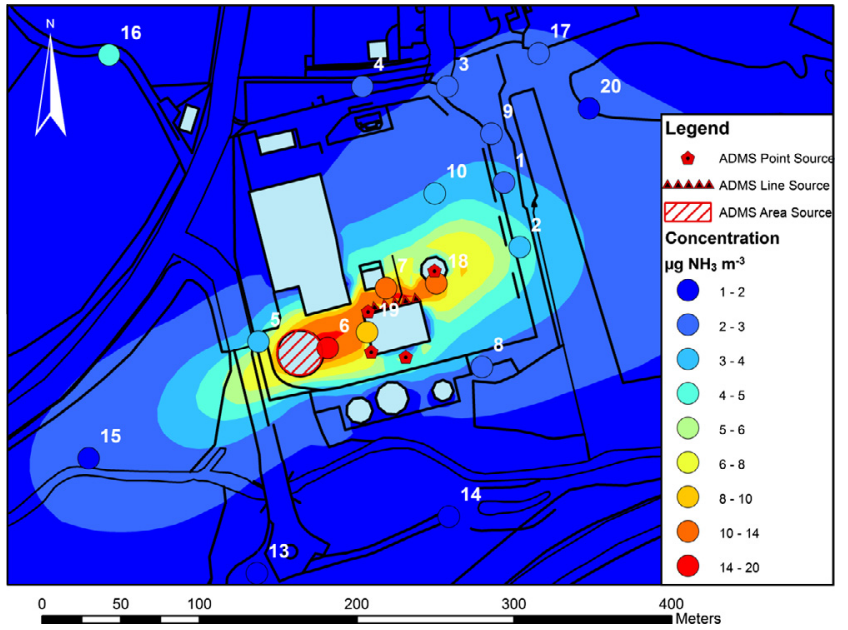

Fig. 9. Contour map of Scenario 3 predicted concentrations. This model shows an excellent fit to the ALPHA measurements and provides the best estimate of the magnitude and distribution of $\mathrm{NH}_{3}$ emissions at Deerdykes. ALPHA measurements are set above the contour predictions, labelled by sample number on the same colourscale for evaluation. (For interpretation of the references to colour in this figure legend, the reader is referred to the web version of this article.)

Optimisation factors were derived after an empirical iterativefit manner, yet there was consideration given to the conceptual model for $\mathrm{NH}_{3}$ emissions from the site, and qualitative expectations of the degree of error associated with the initial emissions assessments. The optimised emission rates are given in Table 4. The predicted concentrations of the optimised model (Scenario 3) are shown in Figs. 8 and 9, where a near-perfect linear regression can be seen between measured and predicted concentrations.

\section{Discussion}

\subsection{Assessment of modelling approach and comparison against measurements}

The aim of this study was to estimate the $\mathrm{NH}_{3}$ emissions from the Deerdykes AD plant. No direct measurements of emissions were made; rather the source strength was inferred through coupling of atmospheric measurements to forward and inverse dispersion modelling, and the estimation of emissions independently of atmospheric measurements through applying literature EFs and models to site parameters.

The Deerdykes AD plant was not ideally suited as a source area for the bLS technique due to the spatial complexity of various sources. The distance between potential sources was greater than the distance from the nearest source to the concentration receptor homogenous area source, which should not be the case to ensure accurate estimates with the bLS method (Flesch et al., 2005). Furthermore, the AiRRmonia concentration sensor was suitably downwind and under the right stability conditions during only $11 / 690$ hourly measurement intervals. The predicted Scenario 1 emission estimate therefore may not be expected to be fully representative of the entire measurement period, and was less than half $\left(7.4 \mathrm{mg} \mathrm{s}^{-1}\right)$ of the best-performing Scenario 3 estimate $\left(16.1 \mathrm{mg} \mathrm{s}^{-1}\right)$. Some concentration predictions were inaccurate close to the source area, and all were generally lower than ALPHA measurements. The prediction of variable emissions between 0 and $25 \mathrm{mg} \mathrm{s}^{-1}$ may describe the periodical nature of emissions from the AD plant, a theory which is supported by large peaks in continuous AiRRmonia concentration measurements made outside of the digestate store (Fig. 7).

According to the Chang and Hanna (2004) evaluation criteria (Table 5), a perfect model would have MG, VG, $\mathrm{R}^{2}$ and $\mathrm{FAC2}=1.0$; and FB and NMSE $=0.0$. Scenario 2 showed considerable bias to overestimate the observed concentrations and as a result the fractional bias (FB) and geometric mean bias (MG) criteria were failed (Table 5), mostly due to the SWBT emission factor being too high. Scenario 3 produced emissions estimates after an iterative-fit-optimisation to the observed concentration field which very closely reproduced the measured concentrations at the individual ALPHA receptors across the model domain. The initial condition of the iterative process was not arbitrary as estimates were produced after analysis of site parameters and reviewing information within the literature, whilst the optimisation process remained sympathetic to this understanding of emissions from the site and the uncertainties therein. The optimised emission factors tuned to the observed concentrations are far from being independent of measurements, therefore performance criteria approaching ideal values would have be to be expected. An independent evaluation was carried out by taking the Scenario 3 optimised emission rates and comparing the predicted and measured concentrations for an earlier (ALPHA Period 1, 15 May-27 May 2014) period with a very different prevailing wind direction. The Scenario 3 emissions estimates were therefore validated with strong performance in all evaluation criteria (Table 5). Scenario 3 also describes the spatial distribution and relative weight of individual sources developed by this methodology, giving a more detailed understanding of the nature of $\mathrm{NH}_{3}$ emissions at the plant. The Scenario 1 bLS-calculated source strength is within the acceptability range for all of the performance measures; however Scenario 3 with six individual sources and a higher total estimate performs much better and is therefore expected to represent the true area-integrated emission rate for this period.

\subsection{Key sources of emissions identified at the site}

The largest source of $\mathrm{NH}_{3}$ at the plant was found to be the digestate store ( $7.3 \mathrm{mg} \mathrm{s}^{-1}, 44 \%$ of total emissions). Continuous AiRRmonia measurements taken over a period of three weeks from $20 \mathrm{~m}$ outside of the digestate store revealed that concentrations were dominated by high-magnitude events during which the air concentration would rise up to $300 \mu \mathrm{g} \mathrm{m}^{-3}$ and return back to a low

Table 5

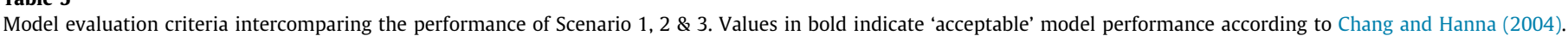

\begin{tabular}{|c|c|c|c|c|c|}
\hline Performance measure & Normalised mean square error (NMSE) & Geometric variance (VG) & Fractional bias (FB) & Geometric mean bias (MG) & FAC2 (\%) \\
\hline $\begin{array}{c}\text { Chang and Hanna (2004) } \\
\text { acceptability criteria }\end{array}$ & $<1.5$ & $<4$ & $<0.3$ & $0.7<\mathrm{MG}<1.3$ & $>50$ \\
\hline Scenario 1 & 0.02 & 1.3 & 0.25 & 1.29 & 95 \\
\hline Scenario 2 & 0.24 & 1.01 & -0.74 & 0.46 & 80 \\
\hline Scenario 3 & 0.02 & 1.18 & -0.06 & 0.95 & 100 \\
\hline Scenario 3 independent Period 1 & 0.03 & 1.01 & -0.16 & 0.85 & 100 \\
\hline
\end{tabular}

FAC2: fraction of model predictions within a factor of two of observations.

ALPHA receptors 12 and 16 are excluded due to the influence of an adjacent dairy farm on measured concentrations. 
baseline $\left(<10 \mu \mathrm{g} \mathrm{m}^{-3}\right)$ within a few hours (Fig. 7). This is consistent with the conceptual model of intense emission events occurring as the digestate store is opened, inducing ventilation and release of the $\mathrm{NH}_{3}$ within the room air of the digestate store, measurements of which were as high as $60 \mathrm{ppm}\left(42 \mathrm{mg} \mathrm{m}^{-3}\right)$. The Deerdykes digestate was found to be very rich in $\mathrm{TKN}$ and $\mathrm{NH}_{4}-\mathrm{N}$, with a high $\mathrm{pH}$, contributing to high emissions estimated by the empirical model of Borka et al. (2000) (Eq. (9)). Estimated fugitive emissions from the waste reception and pre-processing area were low, comprising around $4 \%$ of emissions from the plant. Indoor measured concentrations from the waste reception area at the AD seemed to be around 26 times lower than similar measurements taken from an agricultural AD (Cumby et al., 2005), potentially highlighting differences in the degree of $\mathrm{NH}_{3}$ volatilisation from solid food wastes compared to livestock manure digestion substrates. The SBR was the second greatest source of $\mathrm{NH}_{3}$ at the plant $\left(5.1 \mathrm{mg} \mathrm{s}^{-1}\right.$, $30 \%$ of total emissions), a source which required no correction to fit to observed $\mathrm{NH}_{3}$ concentrations from the initial emission factor (220 $\mathrm{mg} \mathrm{m}^{-2} \mathrm{~h}^{-1}$ ) adopted from the findings of Willers et al. (1996).

If minimising $\mathrm{NH}_{3}$ emissions from the plant were required, it would be an effective course of action for plant operators to concentrate on emissions from the digestate storage area. Very low emissions were occurring at the entrance to the waste reception area, this indoor space is maintained at a negative pressure and connected to the mechanical ventilation and biofilter system, the entrance is also opened and closed rapidly to minimise emissions during deliveries. Connecting the digestate storage compartment to the mechanical ventilation and biofilter system and would reduce the $\mathrm{NH}_{3}$ concentration within the room air and emissions, assuming the $87 \% \mathrm{NH}_{3}$ scrubbing efficiency measured by Cumby et al. (2005). Taking steps to minimise the ventilation rate and exposure to the atmosphere would contribute to further reductions, such as covering the digestate, using the biofilter ventilation system to keep a negative pressure, or streamlining the extraction process to reduce the duration of the entrance being opened.

Applying the emission factor of Willers et al. (1996) to the Deerdykes SBR produced an emission rate that was the second highest on the site (30\% of total emissions). However, the feasibility of minimising emissions from the SBR is likely to be much reduced relative to the digestate store, as emissions from the surface of the tank would need to be contained without interfering with the aerobic treatment process, and the $5 \mathrm{~m}$ tall SBR tank is a greater distance from the biofilter system. Emissions from the SWBT (19\% of emissions) arise after spillages of organic waste materials delivered and processed at the site are channelled into the tank via a drainage network. Therefore an effective strategy to minimise emissions from this source would be to apply further measures to minimise the occurrences of spillages on site.

\subsection{Uncertainty in emission estimates}

The averaged coefficient of variation (CV) between ALPHA triplicates for measurement periods 2-5 ranged from 1.9 to $10.9 \%$, with the average being $4.5 \%$ (Supplementary material). As the downwind air concentration of a pollutant can be assumed to be directly proportional to the source strength (building effects may be exempt from this), a maximum error of $10.9 \%$ may be applied to emission rates that have been deduced by fitting predicted concentrations to those observed at the ALPHA sites. This is quite small relative to the rule-of-thumb of 'plus or minus a factor of two' that has often been adopted to describe the quality of predictions from atmospheric dispersion models (Fox, 1984; Chang and Hanna, 2004). Taking Scenario 3 emission rates and the maximum error observed in the ALPHA measurements, an emission rate for all sources at Deerdykes AD plant $=16.8 \pm 1.8 \mathrm{mg} \mathrm{s}^{-1}$. The emission rates for the Scenario 1 (bLS) and Scenario 2 (initial) estimates were $7.4 \pm 0.8 \mathrm{mg} \mathrm{s}^{-1}$ and $27.5 \pm 3 \mathrm{mg} \mathrm{s}^{-1}$ respectively.

There is however, potential error associated with the ADMS model, which hence impacts upon the assumption that the downwind concentrations will be directly proportional to the source strength. For example, ADMS has been shown to underestimate predicted concentrations relative to measurements in certain case studies (Hanna et al., 2001; Baumann-Stanzer et al., 2008; Theobald et al., 2012). Therefore if ADMS is underestimating concentrations around the AD plant, a greater emission rate will be needed to fit predicted concentrations to the ALPHA measurements. Further, perhaps the defined dry deposition velocity is of $0.02 \mathrm{~ms}^{-1}$ is unsuitable, or simply the single universal deposition velocity is unsufficient for the complexity of the area, and a more advanced canopy resistance model with multiple cover types is required. It is possible to set up a model with inaccurate emission rates and yet still arrive at perfect concentration predictions if overcompensating parameters and variables are not correctly representative. An important parameter with a high uncertainty is $L$, which is not derived from site sonic anemometer measurements as would ideally be the case but has been output from the ADMS meteorological pre-processor using time of day/year, latitude and cloud cover as the proxy for surface heating.

With six discrete sources grouped in a small area, determining individual emission rates by optimising to fit measurements is challenging, as there may be multiple source strength configurations to arrive at the 'correct' predictions. However at Deerdykes buildings and structures add complexity which can isolate certain sources, and the ADMS complex terrain module has the capability to provide accurate predictions where there are building effects (Hill et al., 2001). Non-Gaussian simulated concentration profiles in the wake of the AD plant are visible in Fig. 9. Without direct emission measurements for verification, the applicability of emission factors reported in the literature (Table 4) and close fit between predicted and observed concentrations at passive sampler receptors suggest that emission estimates are robust, reducing the associated uncertainties in qualitative terms.

\subsection{Suitability of emission factors for upscaling}

The measurement period at Deerdykes was relatively short, representative of summer conditions. The volatilisation of $\mathrm{NH}_{3}$ is exponentially related to temperature (Sommer et al., 1991), where emissions can be expected to be higher during summer than the rest of the year. Further measurements would be necessary to determine the seasonal variability in emissions.

The storage and treatment of solid and liquid effluents (digestate store and SBR) were identified as the greatest sources of $\mathrm{NH}_{3}$ at the $\mathrm{AD}$ plant, contributing $74 \%$ of total emissions. The optimised emission factor of Scenario 3 ( $0.0018 \%$ Total FW input volatilised as $\mathrm{NH}_{3}$ ) is likely to be representative of AD plants where the digestate is separated into liquid and solid effluents, the liquid effluents being aerobically treated on-site while solids are stored for a short period of time in a warehouse-type storage unit with no emission control. Ultimately the management of digestate is an economic choice that is up to the operator, ranging from treating as a waste product to marketing as a high-value horticultural soil fertiliser. The UK market for digestate is immature and distribution is largely driven by local circumstances, where spreading of unseparated digestate to agricultural land is the most common end-use (WRAP/EA, 2009). Therefore this emission factor is not likely to be representative of the majority of AD plants. However, the estimated emissions from substrate storage and processing at the plant may well be representative of other community ADs that process source-segregated municipal and industrial wastes. Future investigations into $\mathrm{NH}_{3}$ emissions from $\mathrm{AD}$ plants may benefit from 
focusing on the storage of digestate, preferably taking measurements at sites with isolated digestate storage and treatment facilities. Isolated sources with low topographical complexity create favourable conditions to take advantage of the efficiencies of the bLS method, to give valuable emission estimates and contribute to a representative $\mathrm{EF}$ for this emerging source of $\mathrm{NH}_{3}$ emissions.

\section{Conclusion}

This study has demonstrated an economical methodology for the estimation of $\mathrm{NH}_{3}$ emissions from a complex source. Three different modelling scenarios and approaches are evaluated for quantifying ammonia emissions without direct flux measurements: (1) top-down bLS method, (2) literature EF-based estimates of individual sources, (3) tuning of individual emission rates to observations of the surrounding concentrations. In this case site complexity likely caused significant error in estimating $\mathrm{NH}_{3}$ emissions from the AD plant by the bLS method. Despite the complications, bLS simulations and continuous ambient concentration measurements describe a large degree of temporal variation in emissions due to daily operations on site. In differentiating the source area into six individual sources, the observed concentration field was very accurately reproduced by the ADMS model after optimising the theoretical emission estimates in an iterative-fit process. The total emission from the AD plant thus estimated by a tuned bottomup approach was $16.8 \pm 1.8 \mathrm{mg} \mathrm{s}^{-1}$, which was significantly higher than top-down bLS estimate $\left(7.4 \pm 0.8 \mathrm{mg} \mathrm{s}^{-1}\right)$. According to the tuned (Scenario 3 ) estimates the storage and treatment of solid and liquid fractions of the separated digestate comprised $74 \%$ of total emissions, while the emissions associated with substrates from the biofilter, waste reception area and pre-processing area contributed just $8 \%$. The integrated approach involving the optimisation of emission factors and dispersion models to operation and measurement perspectives demonstrates a practical and useful approach to understanding emissions from facilities such as the AD plant, with potential application to other complex sources of gaseous emissions.

\section{Acknowledgements}

The authors would like to thank Scottish Water Horizons for permitting measurements to be taken at Deerdykes, and the site manager Colin Lindsay for facilitating our requirements on and off site. Thanks to Stefan Reis for providing the ADMS dispersion model and assisting with the project. This work was undertaken as a dissertation project for the degree of MSc Environmental Protection and Management at the University of Edinburgh, with the support of the School of Geosciences and SRUC.

\section{Appendix A. Supplementary material}

Supplementary data associated with this article can be found, in the online version, at http://dx.doi.org/10.1016/j.wasman.2016.06. 002.

\section{References}

Baumann-Stanzer, K., Piringer, M., Polreich, E., Hirtl, M., Petz, E., Bügelmayer, M. 2008. User experience with model validation exercises. In: Proceedings of the 12th International Conference on Harmonisation with Atmospheric Dispersion Modelling for Regulatory Purposes, Cavtat, Croatia, 6-10 October 2008, Croat. Meteorol. J. 43, 52-56.

Bobbink, R., Hicks, K., Galloway, J., Spranger, T., Alkemade, R., Ashmore, M. Bustamante, M., Cinderby, S., Davidson, E., Dentener, F., Emmett, B., Erisman, J.-W., Fenn, M., Gilliam, F., Nordin, A., Pardo, L., de Vries, W., 2010. Global assessment of nitrogen deposition effects on terrestrial plant diversity: a synthesis. Ecol. Appl. 20 (1), 30-59. http://dx.doi.org/10.1890/08-1140.1.
Borka, G., Menzi, H., Neftel, A., Langhans, W., 2000. Development of an empirical model for ammonia emissions from slurry in cattle houses. In: Proc. Conference of the FAO/ESCORENA Network on Recycling Agricultural, Municipal and Industrial Residues in Agriculture (RAMIRAN), Gargnano, Italy, 6-9 September 2000 , pp. 333-335.

Carruthers, D., Holroyd, R., Hunt, J., Weng, W., Robins, A., Apsley, D., Thompson, D., Smith, F., 1994. UK ADMS: a new approach to modelling dispersion in the earth's atmospheric boundary layer. J. Wind Eng. Ind. Aerodynam. 52, 139-153.

Carslaw, D.C., Ropkins, K., 2012. Openair - an R package for air quality data and analysis. Environ. Model. Softw. 27-28, 52-61.

Chang, J.C., Hanna, S.R., 2004. Air quality model performance evaluation. Meteorol. Atmos. Phys. 87 (1), 167-196.

Chynoweth, D.P., Wilkie, A.C., Owens, J.M., 1999. Anaerobic treatment of piggery slurry - review. Asian-Aust. J. Anim. Sci. 12 (4), 607-628.

CLAG, 1994. Critical Load of Acidity in the United Kingdom (1994). Summary Report of the Critical Loads Advisory Group. Institute of Terrestrial Ecology, Penicuik, Midlothian.

Clemens, J., Trimborn, M., Weiland, P., Amon, B., 2006. Mitigation of greenhouse gas emissions by anaerobic digestion of cattle slurry. Agric. Ecosyst. Environ. 112, $171-177$.

Cumby, T., Sandars, D., Nigro, E., Sneath, R., Johnson, G., 2005. Physical Assessment of the Environmental Impacts of Centralised Anaerobic Digestion Report by. Silsoe Research Institute, 112pp.

Draaijers, G.P.J., Ivens, W.P.M.F., Bos, M.M., Bleuten, W., 1989. The contribution of ammonia emissions from agriculture to the deposition of acidifying and eutrophying compounds onto forests. Environ. Pollut. 60 (1), 55-66.

ECN, 2003. AiRRmonia. Energy Research Foundation of the Netherlands, Petten, NL, p. 57.

Environment Agency, 2010. Guidance on Modelling the Concentration and Deposition of Ammonia Emitted from Intensive Farming. Air Quality Modelling and Assessment Unit, 22 November 2010, V3.

European Commission, 2009. Directive 2009/28/EC of the European Parliament and of the council of 23 April 2009 on the promotion of the use of energy from renewable sources and amending and subsequently repealing Directives 2001/ 77/EC and 2003/30/EC. Official Journal of the European Union L 140/16 - 62 5.6.2009.

Faulkner, W.B., Powell, J.J., Lange, J.M., Shaw, B.W., Lacey, R.E., Parnell, C.B., 2007. Comparison of dispersion models for ammonia emissions from a ground-level area source. Trans. ASAE 50, 2189-2197.

Flesch, T., Desjardins, R., Worth, D., 2011. Fugitive methane emissions from an agricultural biodigester. Biomass Bioenergy 35, 2927-3935.

Flesch, T., Wilson, J., Harper, L., Crenna, B., Sharpe, R., 2004. Deducing ground-to-air emissions from observed trace gas concentrations: a field trial. J. Appl. Meteorol. 43, 487-502.

Flesch, T., Wilson, J.D., Harper, L.A., Crenna, B.P., 2005. Estimating gas emission from a farm using an inverse-dispersion technique. Atmos. Environ. 39, 4863-4874.

Flesch, T., Harper, L.A., Powell, J.M., Wilson, J.D., 2009. Inverse-dispersion calculation of ammonia emissions from Wisconsin dairy farms. Trans. ASAE $52,253-265$.

Fox, D.G., 1984. Uncertainty in air quality modeling. Bull. Am. Meteorol. Soc. 65, 2736.

Hanna, S.R., Egan, B.A., Purdum, J., Wagler, J., 2001. Evaluation of the ADMS, AERMOD, and ISC3 dispersion models with the OPTEX, Duke Forest, Kincaid, Indianapolis and Lovett field datasets. Int. J. Environ. Pollut. 16 (1), 301-314.

Hansen, M.N., Birkmose, T., Mortensen, B., Skaaning, K., 2005. Effects of separation and anaerobic digestion of slurry on odour and ammonia emission during subsequent storage and land application. In: Bernal, M.P., Moral, R., Clemente, R., Paredes, C. (Eds.), Sustainable Organic Waste Management for Environmental Protection and Food Safety. FAO and CSIC, Murcia, Spain, pp. 265-269.

Hansen, M.N., Kai, P., Møller, H.B., 2006. Effects of anaerobic digestion and separation of pig slurry on odour emission. Appl. Eng. Agric. 22, 135-139.

Hill, R., Smith, K., Russell, K., Misselbrook, T., Brookman, S., 2008. Emissions of ammonia from weeping wall stores and earth-banked lagoons determined using passive sampling and atmospheric dispersion modelling. J. Atmos. Chem. 59, 83-98.

Hill, R.A., Parkinson, R.J., Pain, B.F., Phillips, V.R., Lowles, I., 2001. Evaluation of the UK-ADMS buildings effects module using data on the near-field dispersion of ammonia at an intensive dairy farm. In: Proceedings of the Seventh International Conference on Harmonisation within Atmospheric Dispersion Modelling for Regulatory Purposes. Joint Research Centre, European Commission, Italy, pp. 239-243.

Holmes, N.S., Morawska, L., 2006. A review of dispersion modelling and its application to the dispersion of particles: an overview of different dispersion models available. Atmos. Environ. 40, 5902-5928.

Jarvis, S.C., 1993. Nitrogen cycling and losses from dairy farms. Soil Use Manage. 9, 99-105.

Kvasauskas, M., Baltrenas, P., 2009. Research on anaerobically treated organic waste suitability for soil fertilization. J. Environ. Eng. Landsc. Manage. 17 (4), 205-211.

Leytem, A., Dungan, S., Bjorneberg, D., Koehn, A., 2010. Emissions of ammonia, methane, carbon dioxide, and nitrous oxide from dairy cattle housing and manure management systems. J. Environ. Qual., 39

Liebetrau, J., Reinelt, T., Clemens, J., Hafermann, C., Friehe, J., Weiland, P., 2013. Analysis of greenhouse gas emissions from 10 biogas plants within the agricultural sector. Water Sci. Technol. 67, 1370-1379. 
Lillyman, C., Buset, K., Mullins, D., 2009. Canadian Atmospheric Assessment of Agricultural Ammonia. National Agri-Environmental Standards, Environment Canada, Gatineau, Que.

Maranon, E., Salter, A.M., Castrillon, L., Heaven, S., Fernandez-Nava, Y., 2011. Reducing the environmental impact of methane emissions from dairy farms by anaerobic digestion of cattle waste. Waste Manage. 31, 1745-1751.

McGinn, S.M., Flesch, T.K., Harper, L.A., Beauchemin, K.A., 2006. An approach for measuring methane emissions from whole farms. J. Environ. Qual. 2006 (35), 14-20.

Misselbrook, T.H., Van der Weerden, T.J., Pain, B.F., Jarvis, S.C., Chambers, B.J., Smith, K.A., Phillips, V.R., Demmers, T.G.M., 2000. Ammonia emission factors for UK agriculture. Atmos. Environ. 34, 871-880.

Møller, J., Boldrin, A., Christensen, T.H., 2009. Anaerobic digestion and digestate use: accounting of greenhouse gases and global warming contribution. Waste Manage. Res. 27, 813-824.

Möller, K., Stinner, W., 2009. Effects of different manuring systems with and without biogas digestion on soil mineral nitrogen content and on gaseous nitrogen losses (ammonia, nitrous oxides). Eur. J. Agron. 30, 1-16.

Nihlgard, B., 1985. The ammonium hypothesis - an additional explanation to forest dieback in Europe. Ambio 14, 2-8.

Pain, B.F., Misselbrook, T.H., Clarkson, C.R., Rees, Y.J., 1990. Odour and ammonia emissions following the spreading of anaerobically-digested pig slurry on grassland. Biol. Wastes 34, 259-267.

Puchalski, M.A., Sather, M.E., Walker, J.T., Lelunann, C.M.B., Gay, D.A., Mathew, J., Robargef, W.P., 2011. Passive ammonia monitoring in the United States: comparing three different sampling devices. J. Environ. Monit. 13, 3156-3167.

Riddick, S.N., Blackall, T.D., Dragosits, U., Daunt, F., Braban, C.F., Tang, Y.S., MacFarlane, W., Taylor, S., Wanless, S., Sutton, M.A., 2014. Measurement of ammonia emissions from tropical seabird colonies. Atmos. Environ. 89, 35-42.

Ross, C.A., Scholefield, D., Jarvis, S.C., 2002. A model of ammonia volatilisation from a daily farm: an examination of abatement strategies. Nutr. Cycl. Agroecosyst. 64, 273-281.
Sommer, S.G., Olesen, J.E., Christensen, B.T., 1991. Effects of temperature, wind speed and air humidity on NH3 emission from surface applied cattle slurry. J. Agric. Sci. Camb. 117, 91-100.

Tang, Y., Cape, J., Sutton, M.A., 2001. Development and types of passive samplers for monitoring atmospheric $\mathrm{NO}_{2}$ and $\mathrm{NH}_{3}$ concentrations. Sci. World 1, 513-529.

Theobald, M.R., Løfstrøm, P., Walker, J., Andersen, H.V., Pedersen, P., Vallejo, A. Sutton, M.A., 2012. An intercomparison of models used to simulate the shortrange atmospheric dispersion of agricultural ammonia emissions. Environ. Model. Softw. 37, 90-102.

Theobald, M.R., Crittenden, P.D., Tang, Y.S., Sutton, M.A., 2013. The application of inverse-dispersion and gradient methods to estimate ammonia emissions from a penguin colony. Atmos. Environ. 81, 320-329.

Vestreng, V., Storen, E., 2000. Analysis of the UNECE/EMEP Emission Data. MSC-W Status Report 2000. Norwegian Meteorological Institute, Blindern, Oslo, Norway.

Vogt, E., Dragosits, U., Braban, C.F., Theobald, M.R., Dore, A.J., van Dijk, N., Tang, Y.S. McDonald, C., Murray, S., Rees, R.M., Sutton, M.A., 2013. Heterogeneity of atmospheric ammonia at the landscape scale and consequences for environmental impact assessment. Environ. Pollut. 179, 120-131.

Whelan, M., Villa, T., 2010. A mass transfer model of ammonia volatilisation from anaerobic digestate. Waste Manage. 30, 1808-1812.

Willers, H., Derikx, P., Ten Have, J., Vin, T., 1996. Emission of ammonia and nitrous oxide from aerobic treatment of veal calf slurry. J. Agric. Eng. Res. 63, 345-352.

WRAP/EA, 2009. Quality Protocol Anaerobic Digestate. End of Waste Criteria for the Production and Use of Quality Outputs from Anaerobic Digestion of SourceSegregated Biodegradable Waste. Waste and Resources Action Programme and Environment Agency.

Wulf, S., Jäger, P., Döhler, H., 2006. Balancing of greenhouse gas emissions and economic efficiency for biogas-production through anaerobic co-fermentation of slurry with organic waste. Agric. Ecosyst. Environ. 112, 178-185.

Wyers, G.P., Oties, R.P., Slanina, J., 1993. A continuous-flow denuder for the measurement of ambient concentrations and surface-exchange fluxes of ammonia. Atmos. Environ. Part A - Gen. Top. 27, 2085-2090. 